\title{
Turkey's National Security Concept - A Major Factor Hindering Membership of the European Union
}

\author{
Richard Rousseau \\ American University of Ras Al Khaimah, United Arab Emirates
}

\begin{abstract}
Although Europeanization is a relatively new concept, the roots of the idea of the Europeanization of security in Western Europe go back to the early days of the European Coal and Steel Community (ECSC) and became manifest after the demise of the USSR, which marked the end of the Cold War. ${ }^{1}$ Therefore, the process of European integration can also be seen as a Europeanization of the security culture of European Union (EU) member states. This Europeanization is a transition from the classical perception of security, based on state-centric high politics (achieving security by military power), to a modern one, that is giving priority to low politics (achieving security by non-military power, through economic and political integration). Hence, the Europeanization of security is actually a process of de-securitization which eliminates security and insecurity concerns from perception. However, non-military security problems and dynamics can also be present in that de-securitization.
\end{abstract}

By contrast, the Turkish state's security culture, which takes its roots from the founders of the Republic, gives priority to high - rather than low - politics. The Turkish state's elite are inclined to look at issues through the lenses of security or insecurity. This Turkish state outlook is a consequence of its securitization tradition in which security problems having no military element in their resolution are considered inferior in importance to military ones. This article shows that acknowledgement of the contradictory natures of the linear transition of Europeanization of security in Western Europe and traditional Turkish security perceptions is crucial in order to grasp one of the main underlying reasons behind Turkey's continuing exclusion from the EU's Common Foreign and Security Policy (CFSP).

\section{Europeanization of Security}

"Western Europe is a security community. In contrast to the expectations of most contemporary theorists of security communities, this has not been achieved by erecting common security structures or institutions, but primarily through a process of desecuritization, a progressive marginalization of mutual security concerns in favor of other issues" . 
Karl Deutsch argued that a security community is formed when actors, especially the political authorities, compromised on peace in the form of international cooperation. ${ }^{3}$ Under certain circumstances, this compromise among political elites could lead to integration. The ECSC, which was established by the Treaty of Paris in 1951, emerged as a result of a compromise between the political elites of France and Germany in Western Europe. The creation of this supranational organization was the first step in the institutionalization of the Europeanization of security. Sworn enemies France and Germany sat at a single table and agreed to transfer their sovereignty rights over resources to a supranational organization on the basis of an equal vote principle. The common goal behind this formation was to combine coal and steel resources, which were crucial for both international security and economic development. It should be underlined that a certain security concern was rooted in the establishment of the ECSC, which sought to prevent history repeating itself on the old continent. In other words, the ECSC was established to prevent the devastating wars the continent has so frequently suffered. During that period, the means of alleviating certain threats ${ }^{4}$ of the repetition of history and to preclude a future war in Europe was seen to be economic and political integration. The ECSC emerged as a non-military response to these security threats. The idea behind the ECSC, which emphasized a low-political solution rather than a state-centered high-political one, brought the transition of security perceptions and the establishment of a brand new security identity for Europeans onto the agenda: the Europeanization of security. The founders of the ECSC believed that cooperation on low-political issues would spill over into analogous cooperation in high-political issues.

"There will be no peace in Europe if States re-establish themselves on the basis of national sovereignty, with all that this implies by way of prestige policies and economic protectionism. If the countries of Europe once more protect themselves against each other, it will once more be necessary to build up vast armies [...] Europe will be reborn yet again under the shadow of fear",

Before analyzing the Europeanization of security, which is a process of desecuritization, the concepts of securitization and de-securitization should be clarified. "The idea of securitization immediately changes security/insecurity from being an exhaustive set of options (the more security, the less insecurity and vice versa) to being only two out of three basic categories. In the case of de-securitization, we have neither security nor insecurity. To talk of a situation as characterized by security means that a threat is articulated but that sufficient counter-measures are felt to be available, in contrast to insecurity with a threat and insufficient defense" ${ }^{\prime 6}$.

Securitization is the traditional way of perceiving events. This outlook analyses security in a foreign policy context by concentrating on the military dimension of action. Other dimensions of security are inferior to securitization. In other words, high politics is given priority rather than low politics. This outlook leaves no possibility for 
functionalist theories to succeed. States that share this viewpoint have little chance of being able to cooperate. Thus, conflict is inevitable.

This European securitization approach caused two world wars prior to 1951 and eliminated cooperation options among them. The need to transform the European securitization outlook in order to forestall a future war on the continent was evident. The new European security identity would be grounded on de-securitization which would give way to functionalist theories of European integration and lead Europeans to integrate. The ECSC emerged as the first institutionalization effort of this desecuritization of Europeans' security perceptions. Consequently, the European Economic Community (EEC), which was established under the 1957 Treaty of Rome, can be considered the second step in this institutionalization of the transition of the European security identity, the Europeanization of security.

Christopher Coker, an academic at the London School of Economics, indicated that in the 1960s Europeans had gained tangible and intangible perceptions of what WWII had been and sought a new European identity. The security perceptions of this new identity would be based on de-securitization, in which low politics would be given priority. This Europeanization of security perceptions was most visible in relations with the United States.

"President of the European Commission, Walter Hallstein indicated that no longer did Europeans consider the West as the collective political personality during one of his visits to Washington in 1961"7. Thus, Hallstein implied that Europeans were transforming their security perceptions; they were Europeanizing their security discernment, and therefore Europe and the United States could no longer be considered one political personality. However, during the Cold War, Europeans did not achieve a foreign policy independent of the United States. The NATO-EC division of labor which ensured European security during the Cold War period prevented Europeans from pursuing an independent foreign policy ${ }^{8}$.

One of the main motives for the establishment of the EU on the basis of low politics was the idea that, unless European states were transformed into parts of a web of economic and political integration mechanisms, security and stability in the continent of Europe would not be permanent. "The EU has been the main format for the continued non-war community and probably for its cultivation of the real security community features in terms of identity and the non-imaginability of war, but this has happened for most of the period in the form of desecuritization! Therefore, the EU has secured the security community not by upgrading joint security activities but on the contrary by doing other things" 
During the Europeanization of security soft governance, common security practices and non-military methods became the fundamental elements of European security culture. Thus, scholars consider the EU a civilian power. ${ }^{10}$

During the early days of the post-Cold War period EU officials expected to pursue a common foreign policy independent of the U.S., whereas Europeans were pleased with the stability underprovided by NATO's umbrella ${ }^{11}$. After the fall of the Berlin Wall, the military threat was no longer considered a primary security concern and the attitudes of EU officials were consolidated. Immigration pressures from East and South, Denmark's rejection of the EU treaty in 1992 and terrorist activities in neighboring countries, especially Turkey, began the fragmentation of the Union which became the primary threat to the European integration process. Hence, these elements, those which could halt the process of integration, were considered the primary security concerns in the post-Cold War period. EU officials attempted to pursue an independent policy and spread their experiences on achieving success within their borders with the second pillar of the EU in the post-Cold War period: the Common Foreign and Security Policy (CFSP). "When these expectations did not turn into realities and especially when the EU officials found it difficult to comply with the politics of the Common Foreign and Security pillar of the EU, past contributions of the EU (the EC, the EEC) to European security were all forgotten"12. This incapability of Europeans to comply with the tenets of CFSP inflamed concerns about the fragmentation of the Union and the integration process. Therefore, integration became a goal in itself. Immigration and terrorism were evaluated as fundamental threats to European integration. Thus, it can be asserted that Europeans securitized the issues that had the potential to impede the integration process and lead to fragmentation. Hence, Europeans attributed the highest security concerns to terrorism in, and immigration from, neighboring countries and, thus, they securitized these issues.

In sum, during the Cold War, under NATO military guarantees, Europeans attempted to alleviate their fears through economic and political integration. This integration process put Europeanization of the security cultures of member states onto the agenda through de-securitization. During the post-Cold War period Europeanization of their security cultures lead EU members to pursue a common foreign policy, independent of the U.S., and share their experiences, achieving success within their borders with the second pillar of the EU, the CFSP. Meanwhile, terrorism and immigration from neighboring countries created pressures which could lead to the fragmentation of the Union and hinder the process of European integration.

Therefore, as the zenith of the Europeanization of security in the old continent, immigration and terrorism are securitized in order to sustain the European integration process. 


\section{Turkey's National Security Concept}

Mesut Y1lmaz, Turkey's former Deputy Prime Minister and leader of the Motherland Party, made a speech on Turkey's national security syndrome on August 4, 2001. Yilmaz's speech created shock waves within the Turkish national security establishment. "Liberals think that it [security syndrome] is a taboo ${ }^{13}$ whereas military and pro-military actors treat it as an ethos ${ }^{14}$, in which the utmost reason of the survival of the state is embedded"15. In his speech, Y1lmaz claimed that the national security syndrome causes distress in Turkish politics through its concomitant failure to conduct the required reforms on human rights and democracy necessary for it to join the EU:

"[...] National security is an essential paradigm, which ultimately aims to preserve the survival of a state. Yet the practice of this concept today [in today's Turkey] seems to work quite the contrary. The term 'national security' has become a conundrum that thwarts every single step to enhancing the future of this country. Turkey could have been the only country which could manage to utilize such a term to cut off all the vital veins of the state [...] and so it happened. The key for change is hidden in the term 'national security.' However it has been virtually impossible to take steps in the attempt of reinforcing the survival and increasing the welfare of our state, repeatedly due to reference to national security. If Turkey wants to make progress, she has to overcome the national security syndrome. The content and circumstances of national security should be opened to public debate. The true key and requisite for turning our face to Europe, and hence change, is to redefine the limits and boundaries of national security. National security deals with the whole nation and so should the nation do with it ${ }^{\text {"16. }}$.

While talking about the national security syndrome, Y1lmaz did not intend to refer to the Turkish state's external security problems with its neighboring countries. In contrast, by using the term 'syndrome,' Y1lmaz implied that the national security concept, which causes struggles with activities that could harm territorial integrity and secularism, is obstructing Turkey's efforts to comply with the political criteria necessary to join the EU. Moreover, Y1lmaz urged the public to discuss and question Turkey's national security concept.

"His primary agenda was to imply that the language of national security was being used as a tool to legitimize the need for a military role. More specifically, it was being utilized by the military establishment and its supporters to prioritize the indivisible and secular character of the regime as more important than the need for democratic reform" ${ }^{\prime 17}$. However, the acquis communautaire of the EU concerning democracy and human rights, which constituted the most difficult part for Turkey, should be complied with in order to start the accession negotiations with the EU in December 2004. Therefore, Turkey should Europeanize its security in order to become a member of the European club. Moreover, Turkey’s deficiency in Europeanizing its national security 
concept is one of the main reasons for Turkey's exclusion from the CFSP, despite its military and geopolitical capabilities.

"The meaning of national security is first and foremost related to threats to state identity, core national values and the ability to protect state sovereignty, to preserve territorial integrity and to maintain autonomy as far as the pro-military is concerned. This point stems from an official definition of national security which tends to serve the essential goal of protecting regime security"18.

Mustafa Kemal, later named Atatürk, during the period between the foundation of the republic in 1923 and his death in 1938 attempted to transform a traditional society into the Turkish republic through the Kemalist concepts of state building and nation building. "The Kemalist revolution had to establish simultaneously the Republic of Turkey, the Turkish people as a nation and the Turk as a citizen with an identity different from being a Muslim subject of the sultan"19. Republicanism, nationalism, populism and secularism constituted the core of Kemalist politics on state building and nation building.

European experiences of nation building were reflected in the developments of republicanism and nationalism: the unequivocal sovereignty of people united in a common nation. Populism was indicated by the communitarian ideas of the Turkish Republic. Secularism legitimized the banning of public activities, political Islamic ones, which could halt the implementation of the Kemalist concepts of state building and national building. "Republicanism, nationalism, populism and secularism not only provided the core of the new state ideology but also served as legitimizing elements for securing the power of the new state elite" ${ }^{\text {20 }}$.

Therefore, the new state elite, on the one hand, attributed to themselves the role of military guardianship in protecting the core principles of Kemalist politics while those same principles legitimized them. "Thus, the Kemalist ideology and military guardianship ethos are the fundamental norms that have determined the survival of all state and non-state institutions in varying degrees. In this sense, the Kemalist ideology is a particular arrangement of political and social concepts, through which the latter obtain specific uncontested meanings" ${ }^{\text {,21 }}$. The first three articles of the 1982 constitution, which stressed the principles of secularism and nationalism of Kemalist politics, and the republican character of the state, were neither open to amendment nor could amendment be proposed. Hence, Kemalist principles of secularism and nationalism were given priority over other ones. Moreover, the principle of nationalism was more adequately defined as the indivisibility of the Turkish state's territory and nation.

"Thus the Turkish republic is based on a constitutional and legal system, the core principles of which are heavily tainted by a historically developed authoritarian 
understanding of the unitary state and its functioning as well as an organic and homogenous understanding of the nation" 22 . This outlook of the Turkish Republic is a product of certain internal and external security concerns which date back to the 1920s. Threats are evaluated according to a state-centered and high-politics approach.

Moreover, military means are used to resolve political and social problems rather than the use of non-military options being considered. Therefore, Turkey confronts difficulties when resolving its culturally heterogeneous society's political and social problems.

In the post-Cold War period, the state elite were mainly concerned with the domestic political problems of the Kurdish issue and the growth of political Islam. In the 1990s, the state elites were concerned by both these internal security concerns and external security threats. In effect, Syria, Iraq, Iran and Armenia and, to a lesser extent, Russia, were considered hostile to the TurkishRepublic ${ }^{23}$. The national security system was kept on high alert and was capable of ensuring that these internal and external threats would not weaken the Turkish Republic and its core Kemalist principles.

"When these perceptions of internal and external threats are combined, it seems that, contrary to the global trend, the end of the Cold War did not lead to softer security perceptions and a less securitized domestic agenda in Turkey"24. This has led the Turkish Armed Forces (TSK) to widen its contour in Turkish politics. This enlarged profile has led Turkey to develop solutions on the basis of high politics. However, the EU does not believe that solutions based on high politics will provide a plausible response to the domestic problems of the Kurdish issue and the growth of political Islam. The EU considers violation of human rights as the main reason behind the terrorist activities of Kurds and political Islam and conceives low political solutions as the appropriate response to the Turkish Republic's concerns.

Although Turkey has a lot to offer the EU in terms of strategic location, proximity to oil-rich resources and its military capabilities, Turkey faces a lot of difficulties in its attempts to join the EU. Moreover, the EU does not allow Turkey to take part in the decision making body of the CFSP. That Turkey will take part in the CFSP decision making body when it becomes a member to the EU is not considered a satisfactory response in Turkey. Temporary institutional solutions could any time lead to a proposal for full Turkish participation in the CFSP.

Therefore, this problem is not related to law ${ }^{25}$. "The actual problem was about the relation between legitimacy of the CSFP and the European identity, and Turkey's extemporaneous attempts to adopt the European identity" 26 . Europeanization of security leads to the formation of a European identity which attributes priority to low politics. Thus, the current European identity is a product of the process of desecuritization, which eventually led to the emergence of the EU. The CFSP exists on 
the basis of spreading this understanding and sharing Europeans' experiences with the outside world ${ }^{27}$.

However, Turkey's security perception is based on traditional state-centered high politics. Hence, Turkey's security culture is incompatible with the EU and its window to the outside world, the CFSP. Therefore, it can be argued that the problem of adapting the Europeanization of security to Turkey's security understanding is one of the main impediments to Turkey's membership of the European Club. In conclusion, Europe is a security community, which is based on the Europeanization of security; it is undergoing a transition and transformation process based on de-securitization. During that process, low-political security concerns have been attributed priority rather than state-centered high politics.

European integration emerged as a low-politics response to certain security concerns during the Cold War. Although there is no longer a specific security concern to address, EU officials have set European integration as a goal in the post-Cold War period. The issues which can impede the process of integration or lead to the fragmentation of the Union are given priority in the security concern hierarchy. The CFSP has emerged as a means for the EU to pursue an independent foreign policy on the basis of its unique European identity and spread its experiences to other parts of the world. However, Turkey's security culture contradicts the principles of the Europeanization of security.

\section{Conclusion}

Turkey's security perception is a traditional state-centered one which gives priority to high politics and attempts to solve its problems on the basis of military power. In contrast to the global trend, Turkey's securitization tradition has not diminished and the Turkish Armed Forces has enlarged its profile, especially whilst dealing with the Kurdish issue and the rise of political Islam, both of which are threats to the core principles of the Turkish Republic. Therefore, the Turkish security identity is not compatible with the European identity, which is a product of the Europeanization of security. This incompatibility of security identities poses the main impediment to Turkey's inclusion in the CFSP. In sum, Turkey should Europeanize its security identity by stressing low-political considerations while dealing with its internal and external threats in order to be a member of the European Club. A peaceful solution to the Cyprus issue has the potential to ignite the process of the Europeanization of Turkish security identity. 


\section{References and notes:}

1. Woods, N. (1996). Explaining International Relations since 1945. New York: Oxford University Press.

2. Waever, O. (1998). Insecurity, Security, and Asecurity in the West European Non-war community. In E. Adler, and M. Barnett, (Ed.), Security Communities (p.69). Cambridge: Cambridge University Press.

3. Deutsch, Karl W. ([1968] 1978). The Analysis of International Relations. Englewood Cliffs, NJ: Prentice-Hall, Inc, 3rd ed. P. 12.

4. The Soviet threat, the communists as an internal political threat, the economic threat, the German question and the threat to return to old order.

5. Monnet, J. (1978). Memoirs (pp. 221-222). Garden City, NY: Doubleday \& Company.

6. Waever, Op. Cit., p.81.

7. Karaosmanoğlu, Ali L. (2003). 'Transatlantik Çatlă̆l: Değişen Kimlikler', Doğu Batı, 23 May, p. 176.

8. Hodge, Carl C. (2002). NATO for a New Century: Atlanticism and European Security. Santa Barbara: ABC-CLIO.

9. Waever, Op. Cit., pp. 91-92.

10. For an elaborate study on the civilian power character of the EU, see Smith, K. (2000). The End of Civilian Power EU: a Welcome Demise or a Cause for Concern?. The International Spectator, XXXV: 2.

11. Reichard, M. (2006). The EU-NATO Relationship: A Legal and Political Perspective. Burlington, VT: Ashgate.

12. Bilgin, P. (2003). Türkiye-AB İlişkilerinde Güvenlik Kültürünün Rolü. In Karadeli (Ed.), Soğuk Savaş Sonrasında Avrupa ve Türkiye, Ankara: Aytaç Yayınevi, p. 203.

13. Taboo: [...] to a particular person or persons; inviolable, sacred; forbidden, unlawful; also said of people under a perpetual or temporary prohibition from certain actions (Oxford English Dictionary).

14. Ethos: the genius of an institution or system (Oxford English Dictionary)

15. Yücel, G. (2004). 'New Dilemmas of Turkish National Security Politics: Old and New Security Concerns and National Development in the Post-1980 Era', The Fourth Kokkalis Graduate Student Workshop at JFK School of Government, Harvard University, 8-9 February 2002, p. 10. Available at: http://www.ksg.harvard.edu/kokkalis/GSW4/YucelPAPER.PDF

16. Ibid., pp. 3-4.

17. Cizre,Ü. (2003). Demythologizing the National Security Concept: the Case of Turkey, Middle East Journal, 57: 2, 213-214.

18. Yücel, Op. Cit., p. 10

19. Kramer, H. (2000). A Changing Turkey: the Challenge to Europe and the United States. Washington, The Brookings Institution, p. 5.

20. Ibid., p. 6 .

21. Yücel, Op. Cit., p. 10.

22. Kramer, Op. Cit., p. 9.

23. Rowe, Elana Wilson (2008). The Multilateral Dimension in Russian Foreign Policy. Hoboken: Taylor \& Francis.

24. Cizre, Op. Cit., p. 216.

25. Frowein, J.A. (2000). Max Planck yearbook of United Nations law. Volume 4.BRILL.

26. Karaosmanoğlu, Ali L. (2001, Şubat 14).Avrupa Güvenlik ve Savunma Kimliği Açısından Türkiye - Avrupa Birliği İlişkileri, Doğu-Batı, p. 163.

27. Allain, J. (2006). The Irish Yearbook of International Law. Volume 1. Oxford: Hart Publishing Ltd. 


\title{
Summary
}

\section{Turkeys National Security Concept - A Major Factor Hindering Membership of the European Union}

\author{
Richard Rousseau, \\ American University of Ras Al Khaimah, United Arab Emirates
}

Turkey's state-centered and traditional security policy gives priority to "high politics" and attempts to solve problems on the basis of military power. In contrast to the global trend, and particularly in the European Union (EU), Turkey's securitization tradition has not changed in the last few decades and its Armed Forces have even enlarged their profile, especially whilst dealing with the Kurdish issue and the rise of political Islam, both of which are threats to the core principles of the Turkish Republic. This article argues that the Turkish security identity is not compatible with the European identity, which is a product of the Europeanization of security. This incompatibility of security identities poses the main impediment to Turkey's inclusion into the EU's Common Foreign and Security Policy (CFSP). Turkey should Europeanize its security identity by stressing low-political considerations while dealing with its internal and external threats in order to be a member of the European Club.

Key words: Turkey, Security, EU, Europe, Peace, CFSP 